\title{
Computational Viromics: Applications of the Computational Biology in Viromics Studies
}

\author{
Congyu $\mathrm{Lu}^{1} \cdot$ Yousong Peng ${ }^{1}$ (D)
}

Received: 2 June 2020 / Accepted: 14 April 2021 / Published online: 31 May 2021

(c) Wuhan Institute of Virology, CAS 2021

Viruses are a kind of biological entities which rely on host cells for survival. Depending on the genetic materials and replication mode, they can be grouped into double-stranded DNA (dsDNA), single-stranded DNA (ssDNA), doublestranded RNA (dsRNA), positive-sense single-stranded RNA (+ssRNA), negative-sense single-stranded RNA (-ssRNA), ssRNA reverse transcriptase viruses (ssRNART) and dsDNA reverse transcriptase viruses (dsDNA-RT) (Walker et al. 2020). Viruses can infect most kinds of biological entities, including viruses, bacteria, archaea and eukaryote (La Scola et al. 2008; Fermin, 2018). They have a great impact on the earth by shaping bacterial population dynamics and balancing the global ecosystem (Suttle, 2007). For humans, viruses, on the one hand, can cause high human morbidity and mortality and serious economic loss (Baud et al. 2020), on the other hand, they can promote and maintain the healthy balance of the gut microbiome (Seo and Kweon, 2019). Besides, some phages can be applied as the therapy of bacterial infections, especially for the bacterial strains resistant to multiple antibiotics (Altamirano and Barr, 2019).

The viromics studies based on the high-throughput sequencing technology have become increasingly popular in recent years, and novel viruses are being discovered at an unprecedented pace (Gregory et al. 2019). For example, the Tara Oceans Project recently identified 195,728 viral populations which were more than 10 times as many as the known global ocean DNA virome (Gregory et al. 2019). However, several challenges exist in analyzing the sequencing data from viromics studies. Firstly, it is difficult to identify all viral nucleotide sequences from the nucleotide sequences that mixed with the sequences of other species and the possible pollutions (Roux et al.

Yousong Peng

pys2013@hnu.edu.cn

1 Bioinformatics Center, College of Biology, Hunan Provincial Key Laboratory of Medical Virology, Hunan University, Changsha 410082, China 2015a; Ren et al. 2017; Fang et al. 2019; Kieft et al. 2020); secondly, the annotation of viral nucleotide sequences is still challenging, especially for those with remote or no homology with the known viruses (Roux et al. 2015b; McNair et al. 2019; Zhang et al. 2019a); thirdly, the taxonomic assignment of novel viruses is difficult due to a lack of a unified classification system for viruses (Low et al. 2019); fourthly, rapid functional characterization of a large number of newly discovered viruses such as identifying the viral hosts is extremely difficult to achieve by using traditional experimental methods (Jofre and Muniesa, 2020). According to the above analysis, an emerging area of computational viromics which is defined as using the computational methods to solve the problems in viromics studies was proposed in the present study. It includes but not limited to the following aspects:

\section{Identification of Viral Genomic Sequences}

The first step of viromics studies is to identify the viral nucleotide sequences from the metagenomic sequencing data which often contain lots of DNA sequences of host cells such as bacteria and human (Edwards and Rohwer, 2005). Both the eukaryotic and prokaryotic viruses are usually identified using approaches based on the homology of marker genes or the genomic sequences with known viral nucleotide sequences, such as ViromeScan (Rampelli et al. 2016). Unfortunately, viruses lack the universal marker genes like the 16s ribosomal RNA (rRNA) in other species. Therefore, the marker genes used for viral sequence identification should be carefully selected to ensure the coverage of viruses. For example, the RNAdependent RNA polymerases (RdRp) can be taken as the marker gene for the RNA viruses (Wolf et al. 2018). Nevertheless, the homology-based methods show a significant limitation when they are used in identifying the viruses with large diversification from the known viruses (Gregory et al. 2019). To overcome the limitation, the 
sequence homology independent methods have been developed (Ren et al. 2017; Fang et al. 2019). For example, the VirFinder identified viral sequences based on the $k$-mer frequencies in the nucleotide sequences (Ren et al. 2017). In addition, the methods such as VIBRANT combining homology-based methods and homology-independent methods were also further developed to improve the viral sequence identification (Kieft et al. 2020).

\section{Annotation of Viral Genomes}

The annotation of viral genomes is important for the further characterization of viruses, and the identification of the genes in viral genomes is most crucial to genome annotation. Currently, there are a large number of methods that can be used for gene prediction (Hyatt et al. 2010; McNair et al. 2019; Zhang et al. 2019a). Although most of them are not designed for viruses, they should be suitable for the gene predictions of viruses since the viruses can use the machinery of their host cells for transcription and translation (Stern-Ginossar et al. 2019). The characteristics of viral genes including the compact gene structure, no or few introns, overlapped or co-transcribed genes, can be incorporated to optimize the gene prediction methods, such as the PHANOTATE and Vgas (McNair et al. 2019; Zhang et al. 2019a). Besides, the combination of several different tools may improve gene predictions (Zhang et al. 2019a). Moreover, the emerging metaproteomics which is defined as large-scale identification and quantification of proteins from microbial communities may help the identification of genes in viromics studies to a great extent (Brum et al. 2016)

\section{Taxonomic Assignment of the Virome}

Most of the newly-discovered viruses lack biological features and cannot be classified by the current classification system proposed by the International Committee on Taxonomy of Viruses (ICTV) (Walker et al. 2020). The usage of viral sequences in virus taxonomy is valid and is supported by the ICTV (Simmonds et al. 2017). Currently, the homology-based methods have been used for taxonomic assignment of the virome. However, they can only be suitable for a small proportion of viruses with sequence homology to those with known taxonomy (Gregory et al. 2020). A comprehensive classification of the whole viral sequence space remains challenging due to the lack of universal marker genes in viruses. The gene content-based methods such as vConTACT and GRAViTy proposed in recent studies can accurately classify viruses and may provide novel frameworks for a unified classification of all viruses (Eloe-Fadrosh, 2019).

\section{Evolution of the Virome}

In the era of viromics, molecular evolution on the virome level can provide a global view on the origin, diversity and evolution of viruses (Wolf et al. 2018; Gregory et al. 2019). Due to the lack of universal marker genes and the large diversity of viral nucleotide sequences, evolutionary analysis was often conducted on a group of viruses which share one or more marker genes (Wolf et al. 2018; Low et al. 2019). For example, Wolf et al. analyzed the origins and evolution of the RNA virome using the RNA-dependent RNA polymerase ( $R d R p$ ) (Wolf et al. 2018). The results obtained from the study determined the evolutionary relationship among the double-stranded RNA, positivestranded RNA and negative-stranded RNA viruses, and revealed the extensive gene module exchange among diverse viruses and the horizontal virus transfer between the distantly related hosts (Wolf et al. 2018).

\section{Host Prediction of Viruses}

The identification of viral hosts is essential for characterizing viruses, as viruses must rely on host cells for survival. Host predictions of eukaryotic viruses have been usually conducted based on viral sequences alone, such as those for influenza viruses and coronaviruses (Xu et al. 2017; Tian, 2020); while those of prokaryotic viruses have been usually conducted based on the similarity of sequence features or sequences between viruses and hosts. At present, two kinds of computational methods have been developed to predict prokaryotic virus hosts based on genomic sequences (Edwards et al. 2016; Ahlgren et al. 2017; Galiez et al. 2017; Lu et al. 2021). The first kind of methods rely on the sequence similarity search between the query viruses and the candidate host genomes since viruses and their hosts may share the same genes and/or short nucleotide sequences such as the spacer sequences used in CRISPR systems (Edwards et al. 2016). This kind of method can usually predict viral hosts with high accuracy, especially the CRISPR-spacer-based method (Edwards et al. 2016). However, they can be only used for a small proportion of viruses since only some viruses have sequence similarities with their hosts (Edwards et al. 2016). Another kind of methods can predict the viral hosts based on the sequence composition similarity between viruses and their hosts, such as the Prokaryotic virus Host Predictor (PHP) (Lu et al. 2021), VirHostMatcher (Ahlgren et al. 2017) and WIsH (Galiez et al. 2017). Although the latter kind of 
Table 1 Illustration of computational methods or case studies in computational viromics.

\begin{tabular}{|c|c|c|c|c|}
\hline Fields & $\begin{array}{l}\text { Methods or case } \\
\text { studies }\end{array}$ & Summary & Advantages & Limitations \\
\hline \multirow{2}{*}{$\begin{array}{l}\text { Identification } \\
\text { of viral } \\
\text { genomic } \\
\text { sequences }\end{array}$} & $\begin{array}{l}\text { VIBRANT (Kieft } \\
\text { et al. } 2020)\end{array}$ & $\begin{array}{l}\text { Recovery, annotation and curation of } \\
\text { microbial viruses from genomic } \\
\text { sequences }\end{array}$ & $\begin{array}{l}\text { Automated; user-friendly; } \\
\text { accurate }\end{array}$ & $\begin{array}{l}\text { Only for prokaryotic virus } \\
\text { detection }\end{array}$ \\
\hline & $\begin{array}{l}\text { ViromeScan } \\
\text { (Rampelli et al. } \\
\text { 2016) }\end{array}$ & $\begin{array}{l}\text { Detect eukaryotic viruses based on the } \\
\text { homologous search method }\end{array}$ & $\begin{array}{l}\text { Customized virus database; } \\
\text { taxonomic assignment }\end{array}$ & $\begin{array}{l}\text { Difficult to identify novel } \\
\text { viruses }\end{array}$ \\
\hline \multirow[t]{2}{*}{$\begin{array}{l}\text { Annotation of } \\
\text { viral } \\
\text { genomes }\end{array}$} & $\begin{array}{l}\text { PHANOTATE } \\
\text { (McNair } \text { et al. } \\
\text { 2019) }\end{array}$ & $\begin{array}{l}\text { Gene annotations in phages based on viral } \\
\text { gene characteristics }\end{array}$ & $\begin{array}{l}\text { Reference-free; predicting } \\
\text { more genes than other gene } \\
\text { callers }\end{array}$ & Only for phages \\
\hline & $\begin{array}{l}\text { Vgas (Zhang et al. } \\
\text { 2019a) }\end{array}$ & $\begin{array}{l}\text { Combining ab initio and similarity-based } \\
\text { method for predicting viral genes }\end{array}$ & High precision and recall rate & $\begin{array}{l}\text { Accuracy needs further } \\
\text { improvement }\end{array}$ \\
\hline \multirow[t]{2}{*}{$\begin{array}{l}\text { Taxonomic } \\
\text { assignment } \\
\text { of the } \\
\text { virome }\end{array}$} & $\begin{array}{l}\text { vConTACT (Eloe- } \\
\text { Fadrosh, 2019) }\end{array}$ & $\begin{array}{l}\text { Classification of prokaryotic virome } \\
\text { based on the gene sharing network }\end{array}$ & $\begin{array}{l}\text { Universal, scalable and } \\
\text { automated }\end{array}$ & $\begin{array}{l}\text { Not for short fragments, } \\
\text { the singleton or outlier } \\
\text { sequences; only tested } \\
\text { for phages }\end{array}$ \\
\hline & $\begin{array}{l}\text { GRAViTy (Eloe- } \\
\text { Fadrosh, 2019) }\end{array}$ & $\begin{array}{l}\text { Classification of eukaryotic viruses at the } \\
\text { family level within each Baltimore } \\
\text { group }\end{array}$ & Concise and clear & $\begin{array}{l}\text { Not for short contigs; only } \\
\text { for eukaryotic viruses }\end{array}$ \\
\hline $\begin{array}{l}\text { Evolution of } \\
\text { the virome }\end{array}$ & $\begin{array}{l}\text { Analyzed the origins } \\
\text { and evolution of the } \\
\text { RNA virome (Wolf } \\
\text { et al. 2018) }\end{array}$ & $\begin{array}{l}\text { Reconstruct the RNA virus evolution } \\
\text { using the RdRp protein, and reveal } \\
\text { extensive gene module exchange and } \\
\text { horizontal virus transfer among diverse } \\
\text { viruses }\end{array}$ & $\begin{array}{l}\text { A far more complete } \\
\text { reconstruction of the } \\
\text { evolution of RNA viruses } \\
\text { than those in previous } \\
\text { studies }\end{array}$ & Only for RNA viruses \\
\hline $\begin{array}{l}\text { Host } \\
\text { prediction } \\
\text { of phages }\end{array}$ & PHP (Lu et al. 2021) & $\begin{array}{l}\text { A Gaussian model for host prediction of } \\
\text { prokaryotic viruses in metagenomics }\end{array}$ & $\begin{array}{l}\text { Accurate, fast and user- } \\
\text { friendly }\end{array}$ & $\begin{array}{l}\text { Accuracy needs further } \\
\text { improvement }\end{array}$ \\
\hline \multirow[t]{2}{*}{$\begin{array}{l}\text { Virus-host } \\
\text { interactions }\end{array}$} & $\begin{array}{l}\text { P-HIPSTer (Lasso } \\
\text { et al. 2019) }\end{array}$ & $\begin{array}{l}\text { Prediction of PPIs between 1,001 human- } \\
\text { infecting viruses and human based on } \\
\text { structure information }\end{array}$ & Comprehensive and accurate & $\begin{array}{l}\text { The codes are not } \\
\text { available }\end{array}$ \\
\hline & $\begin{array}{l}\text { Predict the } \\
\text { receptorome of } \\
\text { human viruses } \\
\text { (Zhang } \text { et al. } 2020 \mathrm{~b} \text { ) }\end{array}$ & $\begin{array}{l}\text { Predicting the receptorome of the human- } \\
\text { infecting virome based on the unique } \\
\text { features of mammalian virus receptors }\end{array}$ & Fast and comprehensive & $\begin{array}{l}\text { Accuracy needs further } \\
\text { improvement; unable to } \\
\text { predict virus-receptor } \\
\text { interactions directly }\end{array}$ \\
\hline $\begin{array}{l}\text { Virus } \\
\text { culturomics }\end{array}$ & $\begin{array}{l}\text { KOMODO } \\
\text { (Oberhardt et al. } \\
\text { 2015) }\end{array}$ & $\begin{array}{l}\text { A platform for recommending microbial } \\
\text { media }\end{array}$ & $\begin{array}{l}\text { Data-rich, user-friendly and } \\
\text { relatively accurate }\end{array}$ & $\begin{array}{l}\text { Only suitable for bacteria } \\
\text { and archaea }\end{array}$ \\
\hline \multirow{2}{*}{$\begin{array}{l}\text { Association } \\
\text { of virome } \\
\text { and human } \\
\text { health }\end{array}$} & $\begin{array}{l}\text { MicroPro (Zhu et al. } \\
\text { 2019) }\end{array}$ & $\begin{array}{l}\text { A data analysis pipeline for analysis of the } \\
\text { association between the microbes in } \\
\text { human body and the complex diseases }\end{array}$ & $\begin{array}{l}\text { Combining both known and } \\
\text { unknown microbial } \\
\text { organisms }\end{array}$ & $\begin{array}{l}\text { Did not consider the } \\
\text { complex interactions } \\
\text { between microbes }\end{array}$ \\
\hline & $\begin{array}{l}\text { HumanVirusFinder } \\
\text { (Zhang } \text { et al. 2019b) }\end{array}$ & $\begin{array}{l}\text { A machine learning model for } \\
\text { identification of human-infecting } \\
\text { viruses from viral metagenomic data }\end{array}$ & $\begin{array}{l}\text { Fast, easy to use, suitable for } \\
\text { genomes,contigs and reads }\end{array}$ & $\begin{array}{l}\text { Limited data used in } \\
\text { training the models }\end{array}$ \\
\hline
\end{tabular}

method predicts viral hosts with lower accuracy than the former, they can be used for any prokaryotic viruses. Viruses can change their hosts or spill over into other species after genetic mutations or recombinations (Letko et al. 2020), which poses a great challenge for the prediction of viral hosts. For better prediction of viral hosts, it is important to understand the host specificity of viruses determined by the interactions between viruses and their hosts.

\section{Virus-Host Interactions}

The complex interactions between virome and hosts are difficult to be resolved in viromics studies (Seo and Kweon, 2019). Besides, novel viruses are being discovered at an unprecedented pace (Gregory et al. 2019). So, the high-throughput experimental techniques and computational methods are in urgent need to analyze the interactions between viruses and their hosts (Lasso et al. 2019; 
Lian et al. 2021; Zhang et al. 2020a, 2020b). The proteinprotein interaction (PPI) prediction methods can help the identification of the interactions between virome and hosts to a great extent (Lasso et al. 2019; Lian et al. 2021). For example, Lasso et al. used the structural information to develop a computational framework to predict the PPIs between 1,001 human-infecting viruses and human, and they obtained a series of new findings about human-virus interactions such as the shared and unique machinery employed across human-infecting viruses and the previously unappreciated cellular circuits that act on humaninfecting viruses (Lasso et al. 2019).

\section{Virus Culturomics}

The virus isolation and cultivation are the basis for further studies of the virus. Culturomics is defined as a systematic method to find the optimum culture conditions such as the culture medium and the incubation temperature for microbial cultivation (Greub, 2012). Many achievements in the field of bacteria culturomics have been obtained (Lagier et al. 2018). For example, Oberhardt et al. integrated known medium databases and a novel prediction tool into a platform that predicts the culture medium given an organism's 16S rRNA sequence (Oberhardt et al. 2015). Moreover, this platform can also predict culture media for new organisms using a transitivity property and a phylogeny-based collaborative filtering method. Similar to the work by Oberhardt et al., it is possible to predict the cell line or tissue that can be used in virus cultivation based on the similarity of genomic sequences and the predicted PPIs between viruses and hosts.

\section{Association of Virome and Human Health}

The virome has a significant impact on human health. Previous studies have shown that the virome is associated with multiple diseases. However, the detailed mechanism is still unknown due to the complex interactions between the virome and their hosts (Clooney et al. 2019). Computational methods are needed to identify the viruses and their roles in causing human diseases. For example, Zhu et al. developed a metagenomic data analysis pipeline, MicroPro, to analyze the association between the microbes in the human body and complex diseases (Zhu et al. 2019). The virome is also closely related to the early warnings of newly emerging viruses. The Global Virome Project (GVP) has estimated that there are 631,000-827,000 unknown viruses with the potential of infecting humans (Carroll et al. 2018). Recent studies have developed machinelearning methods to identify the human-infecting virome based on sequence features (Zhang et al. 2019b). More efforts are needed to validate their usage in applications.

Taken together, this perspective provides an overall view of computational viromics which includes the identification, annotation and taxonomic assignment of viral genomics sequences, phenotype prediction of viruses, evolution of viromes, virus-host interactions, virus culturomics, association of the virome and human health, and so on (Table 1). The computational viromics is still in the beginning stage. Much more computational methods and experimental efforts are needed to characterize the virome and its interactions with the hosts and environments considering the huge diversity of the global virome.

Acknowledgements This work was supported by the National Key Plan for Scientific Research and Development of China (2016YFD0500300) and Hunan Provincial Natural Science Foundation of China (2020JJ3006).

\section{Compliance with Ethical Standards}

Conflict of interest The authors declare that they have no conflict of interest.

Animal and Human Rights Statement This article does not contain any studies with human or animal subjects performed by the author.

\section{References}

Ahlgren NA, Ren J, Lu YY, Fuhrman JA, Sun F (2017) Alignmentfree oligonucleotide frequency dissimilarity measure improves prediction of hosts from metagenomically-derived viral sequences. Nucleic Acids Res 45:39-53

Altamirano FLG, Barr JJ (2019) Phage therapy in the postantibiotic era. Clin Microbiol Rev 32:e00066-e118

Baud D, Qi X, Nielsen-Saines K, Musso D, Pomar L, Favre G (2020) Real estimates of mortality following Covid-19 infection. Lancet Infect Dis 20:773

Brum JR, Ignacio-Espinoza JC, Kim E-H, Trubl G, Jones RM, Roux S, VerBerkmoes NC, Rich VI, Sullivan MB (2016) Illuminating structural proteins in viral "dark matter" with metaproteomics. Proc Natl Acad Sci USA 113:2436-2441

Carroll D, Daszak P, Wolfe ND, Gao GF, Morel CM, Morzaria S, Pablos-Méndez A, Tomori O, Mazet JA (2018) The global virome project. Science 359:872-874

Clooney AG, Sutton TD, Shkoporov AN, Holohan RK, Daly KM, O'Regan O, Ryan FJ, Draper LA, Plevy SE, Ross RP (2019) Whole-virome analysis sheds light on viral dark matter in inflammatory bowel disease. Cell Host Microbe 26:764-778.e5

Edwards RA, Rohwer F (2005) Viral metagenomics. Nat Rev Microbiol 3:504-510

Edwards RA, McNair K, Faust K, Raes J, Dutilh BE (2016) Computational approaches to predict bacteriophage-host relationships. FEMS Microbiol Rev 40:258-272

Eloe-Fadrosh EA (2019) Towards a genome-based virus taxonomy. Nat Microbiol 4:1249-1250

Fang Z, Tan J, Wu S, Li M, Xu C, Xie Z, Zhu H (2019) Ppr-meta: A tool for identifying phages and plasmids from metagenomic fragments using deep learning. GigaScience 8:giz066 
Fermin G (2018) Host range, host-virus interactions, and virus transmission. In: Tennant P, Fermin G, Foster JE (eds) Viruses: molecular biology, host interactions, and applications to biotechnology, 1st edn. Academic Press, London, pp 101-134

Galiez C, Siebert M, Enault F, Vincent J, Söding J (2017) WIsH: Who is the host? Predicting prokaryotic hosts from metagenomic phage contigs. Bioinformatics 33:3113-3114

Gregory AC, Zayed AA, Conceição-Neto N, Temperton B, Bolduc B, Alberti A, Ardyna M, Arkhipova K, Carmichael M, Cruaud C (2019) Marine DNA viral macro-and microdiversity from pole to pole. Cell 177:1109-1123.e1114

Gregory AC, Zablocki O, Zayed AA, Howell A, Bolduc B, Sullivan MB (2020) The gut virome database reveals age-dependent patterns of virome diversity in the human gut. Cell Host Microbe 28:724-740.e8

Greub G (2012) Culturomics: a new approach to study the human microbiome. Clin Microbiol Infect 18:1157-1159

Hyatt D, Chen GL, LoCascio PF, Land ML, Larimer FW, Hauser LJ (2010) Prodigal: Prokaryotic gene recognition and translation initiation site identification. BMC Bioinf 11:119

Jofre J, Muniesa M (2020) Bacteriophage isolation and characterization: phages of escherichia coli. In horizontal gene transfer. Methods Mol Biol 2075:61-79

Kieft K, Zhou Z, Anantharaman K (2020) Vibrant: Automated recovery, annotation and curation of microbial viruses, and evaluation of viral community function from genomic sequences. Microbiome 8:1-23

La Scola B, Desnues C, Pagnier I, Robert C, Barrassi L, Fournous G, Merchat M, Suzan-Monti M, Forterre P, Koonin E (2008) The virophage as a unique parasite of the giant mimivirus. Nature 455:100-104

Lagier JC, Dubourg G, Million M, Cadoret F, Bilen M, Fenollar F, Levasseur A, Rolain JM, Fournier PE, Raoult D (2018) Culturing the human microbiota and culturomics. Nat Rev Microbiol 16:540-550

Lasso G, Mayer SV, Winkelmann ER, Chu T, Elliot O, PatinoGalindo JA, Park K, Rabadan R, Honig B, Shapira SD (2019) A structure-informed atlas of human-virus interactions. Cell 178:1526-1541.e16

Letko M, Seifert SN, Olival KJ, Plowright RK, Munster VJ (2020) Bat-borne virus diversity, spillover and emergence. Nat Rev Microbiol 18:461-471

Lian X, Yang X, Yang S, Zhang Z (2021) Current status and future perspectives of computational studies on human-virus proteinprotein interactions. Brief Bioinf. https://doi.org/10.1093/bib/ bbab029

Low SJ, Džunková M, Chaumeil P-A, Parks DH, Hugenholtz P (2019) Evaluation of a concatenated protein phylogeny for classification of tailed double-stranded DNA viruses belonging to the order caudovirales. Nat Microbiol 4:1306-1315

Lu C, Zhang Z, Cai Z, Zhu Z, Qiu Y, Wu A, Jiang T, Zheng H, Peng Y (2021) Prokaryotic virus host predictor: a gaussian model for host prediction of prokaryotic viruses in metagenomics. BMC Biol 19:5
McNair K, Zhou C, Dinsdale EA, Souza B, Edwards RA (2019) Phanotate: A novel approach to gene identification in phage genomes. Bioinformatics 35:4537-4542

Oberhardt MA, Zarecki R, Gronow S, Lang E, Klenk H-P, Gophna U, Ruppin E (2015) Harnessing the landscape of microbial culture media to predict new organism-media pairings. Nat Commun 6:8493

Rampelli S, Soverini M, Turroni S, Quercia S, Biagi E, Brigidi P, Candela M (2016) Viromescan: a new tool for metagenomic viral community profiling. BMC Genom 17:1-9

Ren J, Ahlgren NA, Lu YY, Fuhrman JA, Sun F (2017) Virfinder: A novel k-mer based tool for identifying viral sequences from assembled metagenomic data. Microbiome 5:69

Roux S, Enault F, Hurwitz BL, Sullivan MB (2015a) Virsorter: mining viral signal from microbial genomic data. PeerJ 3: e985

Roux S, Hallam SJ, Woyke T, Sullivan MB (2015b) Viral dark matter and virus-host interactions resolved from publicly available microbial genomes. Elife 4: e08490

Seo SU, Kweon MN (2019) Virome-host interactions in intestinal health and disease. Curr Opin Virol 37:63-71

Simmonds P, Adams MJ, Benkő M, Breitbart M, Brister JR, Carstens EB, Davison AJ, Delwart E, Gorbalenya AE, Harrach B (2017) Consensus statement: Virus taxonomy in the age of metagenomics. Nat Rev Microbiol 15:161-168

Stern-Ginossar N, Thompson SR, Mathews MB, Mohr I (2019) Translational control in virus-infected cells. Cold Spring Harb Perspect Biol 11:a033001

Suttle CA (2007) Marine viruses-major players in the global ecosystem. Nat Rev Microbiol 5:801-812

Tian BP (2020) The potential intermediate hosts for SARS-CoV-2. Front Microbiol 11:580137

Walker PJ, Siddell SG, Lefkowitz EJ, Mushegian AR, Adriaenssens EM, Dempsey DM, Dutilh BE, Harrach B, Harrison RL, Hendrickson RC (2020) Changes to virus taxonomy and the statutes ratified by the international committee on taxonomy of viruses (2020). Arch Virol 165:2737-2748

Wolf YI, Kazlauskas D, Iranzo J, Lucía-Sanz A, Kuhn JH, Krupovic M, Dolja VV, Koonin EV (2018) Origins and evolution of the global rna virome. Mbio 9:e02329-18

Xu B, Tan Z, Li K, Jiang T, Peng Y (2017) Predicting the host of influenza viruses based on the word vector. PeerJ 5:e3579

Zhang KY, Gao YZ, Du MZ, Liu S, Dong C, Guo FB (2019a) Vgas: a viral genome annotation system. Front Microbiol 10:184

Zhang Z, Cai Z, Tan Z, Lu C, Peng Y (2019b) Rapid identification of human-infecting viruses. Transbound Emerg Dis 66:2517-2522

Zhang Z, Yu F, Zou Y, Qiu Y, Wu A, Jiang T, Peng Y (2020a) Phage protein receptors have multiple interaction partners and high expressions. Bioinformatics 36:2975-2979

Zhang Z, Ye S, Wu A, Jiang T, Peng Y (2020b) Prediction of the receptorome for the human-infecting virome. Virol Sin 36:133-140

Zhu Z, Ren J, Michail S, Sun F (2019) Micropro: Using metagenomic unmapped reads to provide insights into human microbiota and disease associations. Genome Biol 20:154 